\title{
Article
}

\section{Gene Expression Studies in Formalin-Fixed Paraffin-Embedded Samples of Cutaneous Cancer: The Need for Reference Genes}

\author{
Omar García-Pérez ${ }^{1,2,3}$, Leticia Melgar-Vilaplana ${ }^{4}$, Elizabeth Córdoba-Lanús 1,2,3,*,+(D) \\ and Ricardo Fernández-de-Misa $1,2,5, *,+\mathbb{D}$ \\ 1 Research Unit, Hospital Universitario Nuestra Señora de Candelaria, Ctra. Gral. del Rosario, 145, \\ 38010 Santa Cruz de Tenerife, Spain; omargp6@gmail.com \\ 2 Universidad de La Laguna, Calle Padre Herrera, s/n, 38200 San Cristóbal de La Laguna, Spain \\ 3 Instituto Universitario de Enfermedades Tropicales y Salud Pública de Canarias (IUETSPC), \\ 38296 San Cristóbal de La Laguna, Spain \\ 4 Pathology Department, Hospital Universitario Nuestra Señora de Candelaria, Ctra. Gral. del Rosario, 145, \\ 38010 Santa Cruz de Tenerife, Spain; leticiamvfreedom@hotmail.com \\ 5 Dermatology Department, Hospital Universitario Nuestra Señora de Candelaria, Ctra. Gral. del Rosario, 145, \\ 38010 Santa Cruz de Tenerife, Spain \\ * Correspondence: acordoba@ull.edu.es (E.C.-L.); rfdezdemisa@me.com (R.F.-d.-M.) \\ + E.C.-L. and R.F.-d.-M. shared senior authorship.
}

check for updates

Citation: García-Pérez, O.; Melgar-Vilaplana, L.; Córdoba-Lanús, E.; Fernández-de-Misa, R. Gene Expression Studies in Formalin-Fixed Paraffin-Embedded Samples of Cutaneous Cancer: The Need for Reference Genes. Curr. Issues Mol. Biol. 2021, 43, 2167-2176. https:// doi.org/10.3390/cimb43030151

Academic Editor: Juozas Lazutka

Received: 18 October 2021

Accepted: 29 November 2021

Published: 30 November 2021

Publisher's Note: MDPI stays neutral with regard to jurisdictional claims in published maps and institutional affiliations.

Copyright: (c) 2021 by the authors. Licensee MDPI, Basel, Switzerland. This article is an open access article distributed under the terms and conditions of the Creative Commons Attribution (CC BY) license (https:/ / creativecommons.org/licenses/by/ $4.0 /)$.

\begin{abstract}
Formalin-fixed paraffin-embedded (FFPE) tumour samples may provide crucial data regarding biomarkers for neoplasm progression. Analysis of gene expression is frequently used for this purpose. Therefore, mRNA expression needs to be normalized through comparison to reference genes. In this study, we establish which of the usually reported reference genes is the most reliable one in cutaneous malignant melanoma (MM) and cutaneous squamous cell carcinoma (CSCC). ACTB, TFRC, HPRT1 and TBP expression was quantified in 123 FFPE samples (74 MM and 49 CSCC biopsies) using qPCR. Expression stability was analysed by NormFinder and Bestkeeper softwares, and the direct comparison method between means and SD. The in-silico analysis with BestKeeper indicated that HPRT1 was more stable than ACTB and TFRC in MM (1.85 vs. 2.15) and CSCC tissues (2.09 vs. 2.33). The best option to NormFinder was ACTB gene (0.56) in MM and TFRC (0.26) in CSCC. The direct comparison method showed lower SD means of ACTB expression in MM (1.17) and TFRC expression in CSCC samples (1.00). When analysing the combination of two reference genes for improving stability, NormFinder indicated HPRT1 and $A C T B$ to be the best for MM samples, and HPRT1 and TFRC genes for CSCC. In conclusion, HPRT1 and ACTB genes in combination are the most appropriate choice for normalization in gene expression studies in MM FFPE tissue, while the combination of HPRT1 and TFRC genes are the best option in analysing CSCC FFPE samples. These may be used consistently in forthcoming studies on gene expression in both tumours.
\end{abstract}

Keywords: reference gene; malignant melanoma; cutaneous squamous cell carcinoma; qPCR; formalin-fixed paraffin-embedded

\section{Introduction}

The incidence and mortality rate in cutaneous malignant melanoma (MM) and cutaneous squamous cell carcinoma (CSCC) continue increasing every year. [1,2]. Progress has been made in the search of biomarkers as potential predictors for progression to metastatic disease, resistance to treatment and relapse of the disease [3]. Nevertheless, behaviour of the disease in each patient remains largely unpredictable. Thus, further identification of multiple co-expressed biomarkers or characteristic biomarker's patterns [3-5] are crucial for an accurate approach to patients suffering cancer.

Formalin fixation and paraffin-embedding (FFPE) for biopsies or excisions is the main tissue preservation technique [6,7] and a useful tool for retrospective studies regarding 
skin cancer. It allows tissue samples to be kept for long periods of time, but a significant degradation of nucleic acids along the procedure is the main handicap [8]. It may be due to cross-linking and/or oxidative deamination of mRNA. This issue may account for poor mRNA quality and integrity that hampers subsequent gene expression studies. An improved and robust technique allowing FFPE tissue to be reliably analysed for its RNA content will facilitate the design of useful retrospective studies.

The real time PCR is the most accurate and reliable molecular biology technique in gene expression studies for validation of candidate biomarkers $[9,10]$. However, in these kinds of studies, it is important to consider several subjects: the quality of the sample, the RNA isolation procedure, the stability and degradation of the RNA, the retrotranscription to CDNA, and the qPCR technique [11]. Thus, comparing the relative mRNA expression of a series of samples needs to normalize the quantitative variations of isolated RNA, the integrity of the RNA and the efficiency of the reverse transcription [12] from one sample to another. The use of reference genes as internal controls is the most common method for normalizing mRNA data but its use needs to be experimentally validated for specific tissues or cell types and specific experimental designs [13]. Unfortunately, these issues are still largely ignored, and many reported studies contain poorly normalized qPCR data [14]. The expression of reference genes should remain constant among different tissues and under different experimental conditions [15]. Otherwise, gene expression studies report on misleading conclusions [16-18]. The most widely reported reference genes are housekeeping genes such as glyceraldehyde 3-phosphate dehydrogenase (GAPDH), $\beta$-actin $(A C T B)$ and 18S rRNA ribosomal RNA (18S rRNA), but they still lack conclusive validation of its robustness [19].

Definite results concerning reference genes suitable for gene expression studies in FFPE samples of CSCC and MM are scarce. ACTB, hypoxanthine phosphoribosyltransferase 1 (HPRT1), TATA-box binding protein (TBP) and transferrin receptor (TFRC) genes were reported to show a minimal average variation in FFPE and frozen tissue samples of melanoma and other diseases [20-23]. HPRT1 stably expresses in melanocytic cell lines [24] as well as in laryngeal cancer [25]; as does the $A C T B$ gene in FFPE samples of lung squamous cell carcinoma [26,27], and TBP and TFRC in FFPE breast cancer samples [21,28]. The aim of the current study is to evaluate the usefulness of ACTB, HPRT1, TBP and TFRC as candidate reference genes for mRNA expression studies, including CSCC and MM FFPE samples. Establishing the best reference gene will improve the quality of forthcoming expression studies on CSCC or MM samples.

\section{Materials and Methods}

\subsection{Patients and Study Samples}

One hundred and twenty-three FFPE skin samples corresponding to 123 patients were included (49 CSCC and 74 MM). Patients were followed by the Dermatology Department of Hospital Universitario Nuestra Señora de Candelaria (Santa Cruz de Tenerife, Spain). Their main features are shown in Table 1. The study was approved by the local Ethics Committee (C.P. MO-C.I. PI-57/17 and C.P. MO—C.I. PI-39/14).

\subsection{Candidate Genes}

Four reference candidate genes were selected out of a set of significant genes previously reported in the literature [20-28]: ACTB, TFRC, HPRT1 and TBP (Table 2).

\subsection{RNA Isolation and Integrity}

From each healthy skin and tumour paraffin block, 3-6 sections of 5-20 $\mu$ m were sliced for histochemical detection. We discarded the first slice to avoid contamination. Subsequently, all sections were macrodissected before RNA purification. RNA was isolate from FFPE tissue using the "RNeasy FFPE kit" (Qiagen Inc., Hilden, Germany). We used a deparaffinizer solution recommended by the supplier to increase the amount of RNA and its integrity. RNA concentration was measured using the NanoDrop ND-1000 
spectrophotometer (Thermo Fisher Scientific Inc., Waltham, MA, USA). The integrity of the RNA was confirmed by the amplification of the human ACTB gene by conventional PCR once the RNA was transcribed. Therefore, primers pair that amplified a fragment as short as of $60 \mathrm{bp}$ were designed using the Bioinformatics tool Primers3 v. 0.4 .0 software. Primers extended through two exons of the human $A C T B$ gene to rule out contamination by genomic DNA. The primers sequences were as follows: FW $5^{\prime}$-CTCTTCCAGCCTTCCTTCCT- $3^{\prime}$ and RV 5'-TTGAAGGTAGTTTCGTGGATG-3'.

Table 1. Main clinic-pathological features of included individuals.

\begin{tabular}{|c|c|c|c|}
\hline & & Melanoma * & $\begin{array}{c}\text { Squamous Cell } \\
\text { Carcinoma }\end{array}$ \\
\hline \multicolumn{2}{|c|}{ Number of Patients } & 74 & 49 \\
\hline \multicolumn{2}{|c|}{ Male/Female Ratio } & 0.8 & 1.6 \\
\hline \multicolumn{2}{|c|}{ Median Age at Diagnosis (y) } & 68 & 75 \\
\hline \multirow{3}{*}{ Location $n(\%)$} & Trunk & $13(18)$ & $3(6)$ \\
\hline & Limbs & $47(63)$ & $8(16)$ \\
\hline & Head or neck & $14(19)$ & $38(78)$ \\
\hline \multirow{2}{*}{ Stage $^{\#} n(\%)$} & I-II & $53(72)$ & 49 (100) \\
\hline & III-IV & $21(28)$ & $0(0)$ \\
\hline \multicolumn{2}{|c|}{ Disease Progression $n(\%)$} & $36(49)$ & $13(27)$ \\
\hline
\end{tabular}

\# Stage at diagnosis. ${ }^{*}$ Cutaneous primary malignant melanoma. ${ }^{+}$Cutaneous primary squamous cell carcinoma.

Table 2. Candidates for reference genes in CSCC and MM FFPE samples.

\begin{tabular}{cllcc}
\hline Gene & \multicolumn{1}{c}{ Tittle } & Accession No. & $\begin{array}{c}\text { Amplicon Size } \\
\left(\mathbf{b} \mathbf{p}^{\#)}\right.\end{array}$ & TaqMan Assay \\
\hline ACTB & Beta-actin & NM_001101 & 63 & Hs01060665_g1 \\
\hline TFRC & $\begin{array}{l}\text { Transferrin } \\
\text { receptor }\end{array}$ & NM_003234 & 66 & Hs00951083_m1 \\
\hline HPRT1 & $\begin{array}{l}\text { Hypoxanthine } \\
\text { phosphoribosyl- } \\
\text { transferase 1 }\end{array}$ & NM_000194 & 82 & Hs02800695_m1 \\
\hline TBP & $\begin{array}{l}\text { TATA-box } \\
\text { binding protein }\end{array}$ & NM_001172085 & 91 & Hs00427620_m1 \\
\hline
\end{tabular}

\# bp: base pair.

\subsection{Retrotranscription and Preamplification}

For the synthesis of the second strand of RNA we used the "High Capacity cDNA Reverse Transcription Kit" (Thermo Fisher Scientific Inc., Waltham, MA, USA). The obtained cDNA was preamplified using a TaqMan ${ }^{\circledR}$ PreAmp Master Mix (Thermo Fisher Scientific Inc., Waltham, MA, USA), which amplifies small amounts of cDNA without introducing amplification bias. The concentration used to carry out the pre-amplifications was $8 \mathrm{ng} / \mu \mathrm{L}$, diluted 1:5 and run in a thermocycler under the following conditions: 14 cycles of $95^{\circ} \mathrm{C}$ for $15 \mathrm{~s}$ and $60^{\circ} \mathrm{C}$ for $4 \mathrm{~min}$ (after activation of the polymerase at $95^{\circ} \mathrm{C}$ for $10 \mathrm{~min}$ ). Primer pairs and specific probes of interest were used at a concentration of $0.05 \times$ in a final $10 \mu \mathrm{L}$ pre-amp reaction.

\subsection{Reference Genes Expression by qPCR}

The relative gene expression quantification was performed using a "TaqMan Gene Expression Master Mix" (10×) (Applied Biosystems, Foster City, CA, USA) in a final reaction volume of $10 \mu \mathrm{L}$ in a Step One Plus (Applied Biosystems, Foster City, CA, USA) 
real-time PCR detection machine. TaqMan predesigned probes (Thermo Fisher Scientific Inc., Waltham, MA, USA) for the four housekeeping ACTB /TFRC/HPRT1/TBP genes that were used for this study (Table 2). Every sample was run in triplicate. A non-template control was included in every reaction. A control sample was used as an internal calibrator and run in every plate to normalize for inter-plate variation.

\subsection{Statistical Analysis}

Clinical features of the samples are shown as: relative frequency of each category, 50th percentiles (5-95th), and non-normal and average scale \pm SD, as appropriate. For the comparative analysis, a $t$-Student, chi-squared, Fisher exact, and a Kruskal-Wallis test were used to analyse differences in means and proportions of gene expression between studied groups. The statistical analysis was carried out with the SPSS vs. 25.0 software (IBM Corp, Armonk, NY, USA).

Bestkeeper software (Technical University of Munich, Germany) [29], NormFinder algorithm (Aarhus University Hospital, Denmark) [30] and the direct comparison method between means and standard deviations of the relative gene expression between different samples tissues were used. $p$-values $<0.05$ were considered as statistically significant.

\section{Results}

\subsection{Primer Specificity and RT-qPCR Amplification Efficiency}

ACTB gene expression was found in $100 \%$ of CSCC samples and $94.6 \%$ of MM samples. TFRC gene expression was detected in $87.7 \%$ of CSCC samples and in $80 \%$ of MM samples. HPRT1 gene expression was detected in $80 \%$ of CSCC samples and $81 \%$ of MM samples (Figure 1). TBP was excluded for further analysis because its gene expression was detected in less than $40 \%$ of CSCC and MM samples.
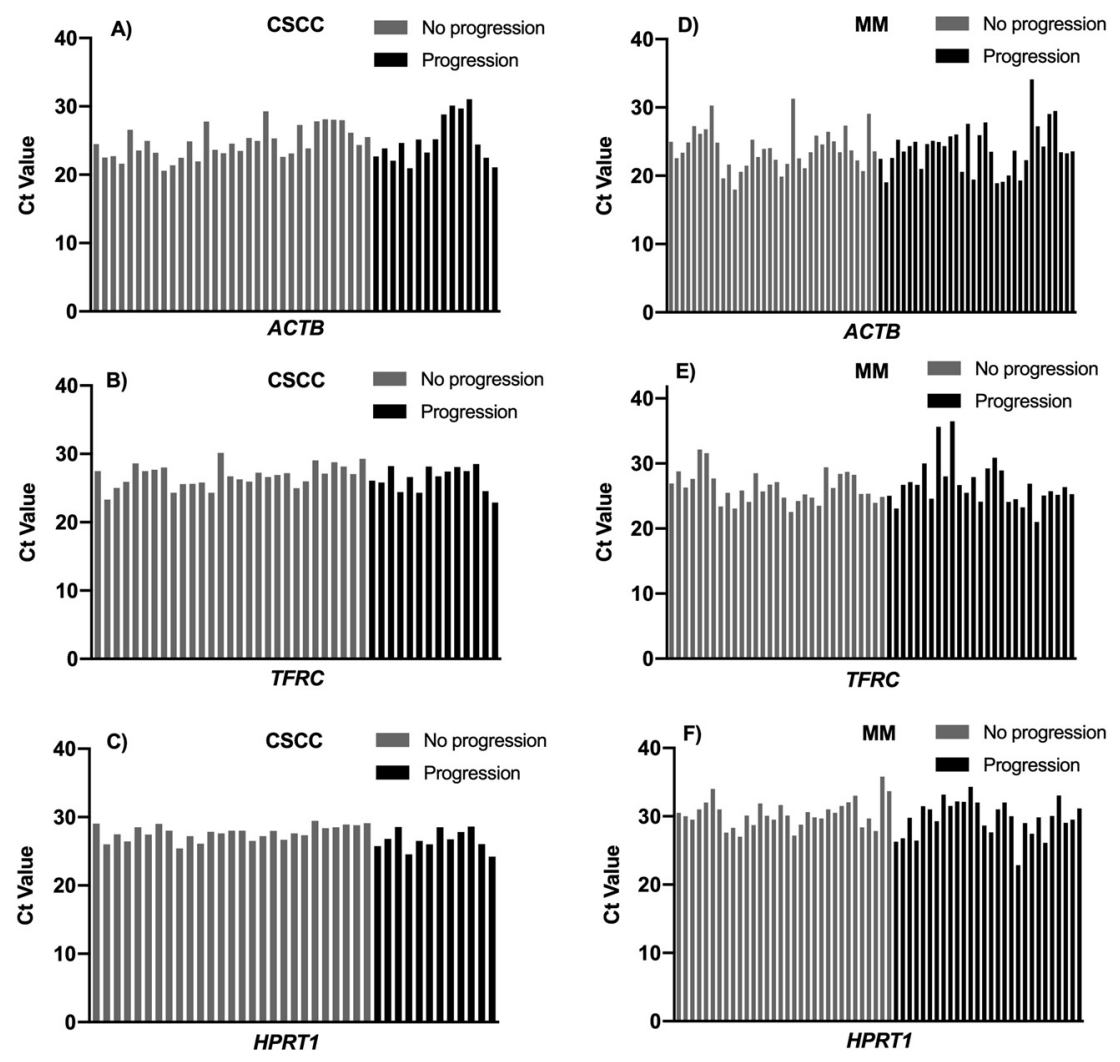

Figure 1. (A-F): Distribution of the raw $\mathrm{Ct}$ values of $A C T B, T F R C$ and HPRT1 in each of the analysed samples of CSCC and MM with and without progression. 


\subsection{Gene Expression Profiling}

The expression profiling of $A C T B, T F R C$ and HPRT1 as candidates reference genes in all samples was determine by the $\mathrm{Ct}$ value (cycle threshold) from RT-qPCR experiments. These three genes exhibited different expression levels across all samples. When comparing these genes, the Ct values ranged between 20.57 and 31.05 in CSCC samples (Figure 2). The minimum and maximum $\mathrm{Ct}$ values observed for MM tissues were 17.99 and 36.47 cycles, respectively.
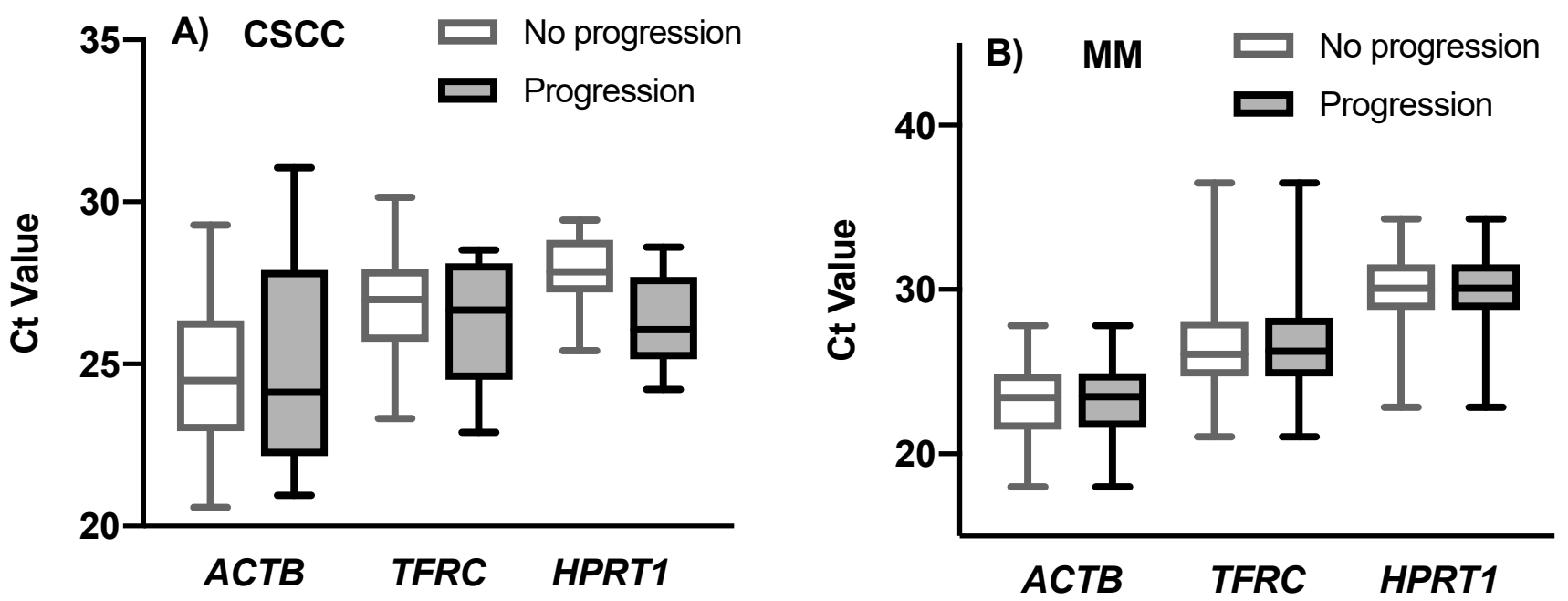

Figure 2. (A,B) Relative expression of the candidate reference genes ACTB, TFRC and HPRT1 in MM and CSCC samples with progression vs. no progression of the disease. The boxes indicate median (25-75\% percentiles) and the whiskers represent the minimum to maximum range.

\subsection{Expression Stability of the Candidate Reference Gene}

The analysis with NormFinder software (Aarhus University Hospital, Denmark) showed that $A C T B$ was the most stable gene in MM, and TFRC in CSCC samples, showing the lowest intra-group and inter-group expression variability in each case. For MM samples, the stability value was 0.56 , and for CSCC it was 0.26 (Figure 3A). The stability analysis with BestKeeper software (Technical University of Munich, Germany) indicated that HPRT1 was the most stably expressed gene in cutaneous MM tissues when compared to ACTB (1.68 vs. 1.85) and TFRC (1.68 vs. 2.15). The same was found for CSCC tissues, where HPRT1 was the most stable expressed gene followed by ACTB (1.04 vs. 2.09) and TFRC (1.04 vs. 2.33) (Figure 3B). Using NormFinder software, the best combination of two reference genes for normalizing CSCC tissue were TFRC and HPRT1 (stability value 0.08), and for MM, HPRT1 and ACTB were the most stable combination (0.14) (Figure 3A). In these cases, while using the calculations required in the normalization method chosen (for example: $2^{-\triangle \triangle \mathrm{Ct}}$ method), an average of the $\mathrm{Ct}$ values of the two reference genes must be calculated for each sample. Then, the resulting $\mathrm{Ct}$ value will be used for correcting the target gene $\mathrm{Ct}$ value. 

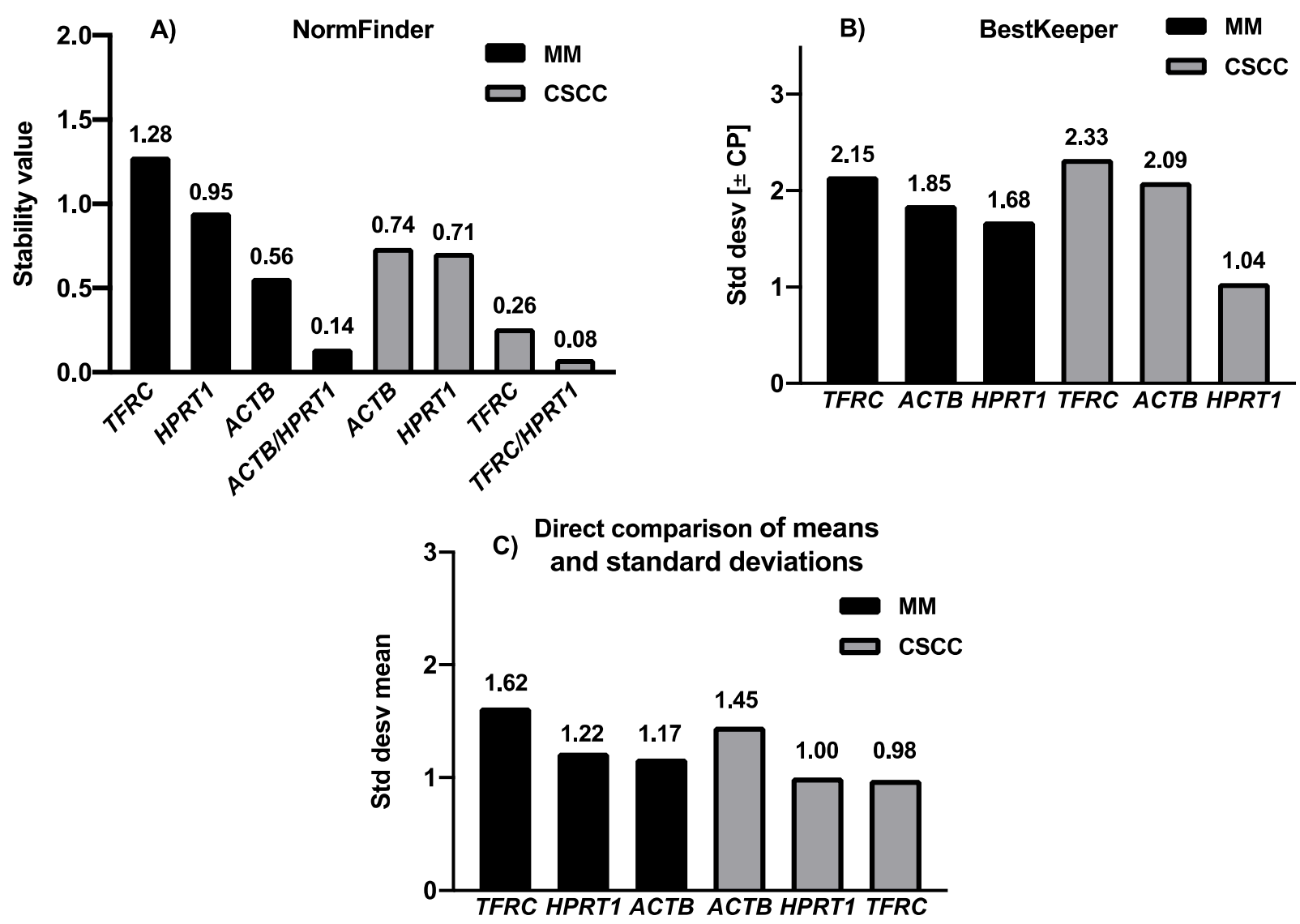

Figure 3. Candidate reference genes stability values (A). NormFinder analysis; lower values indicate high stability (B). BestKeeper analysis; lower SD of Ct values indicate less variable expression (C). Direct comparison of means and standard deviations: lower SD of $\mathrm{Ct}$ values indicate less variable expression.

When using direct comparison of means and standard deviations, we identified the intra and intergroup variability between CSCC and MM, with progression and without disease progression. The most stable expressed gene in MM cancer tissues was $A C T B$ (Figures 1D and 3C), with a lower average between mean SD and mean $\mathrm{Ct}$ (1.17 for $A C T B$; 1.22 for HPRT1; 1.62 for TFRC), while in CSCC cancer tissues it was TFRC (1.00 for TFRC; 1.13 for HPRT1; 1.45 for ACTB) (Figures 1C and 3C).

\section{Discussion}

Our goal was to establish the best reference gene for studies involving gene expression analysis in CSCC and MM FFPE samples out of a pre-selected set of genes. We studied the potential role of $A C T B, T F R C, H P R T 1$ and TBP as reference genes. These genes have cell maintenance functions and are expressed in all cell types of an organism under physiological and pathological conditions. These constitutive genes are essential for the preservation of basic cellular functions [31].

We demonstrated that HPRT1 was the most stable reference gene in CSCC and MM FFPE tissue in comparison with $A C T B$ or TFRC when we used Bestkeeper software. On the other hand, when using NormFinder software or direct comparison of means and standard deviations, $A C T B$ and TFRC were the most appropriate genes for analysing gene expression in FFPE samples of MM and CSCC, respectively. These three genes were widely used in previous expression studies $[7,22,24,32]$ in MM skin samples, but not in CSCC tissues.

Recently, Christensen et al., tested 24 possible reference genes for gene expression studies in MM FFPE samples and purposed a combined geometric mean of CLTA, MRPL19 and $A C T B$ expression levels as the most adequate formula for normalization of gene expression studies in MM tissue [7]. They reported that ACTB alone is not adequate as 
a gene expression normalizer. Our results agree with this study because our analyses significantly improve the variation when we used the combination of ACTB and HPRT1, so this result supports their use in further gene expression studies in MM tumour samples for more reliable results.

TFRC has been studied as a reference gene in several types of tissues and different diseases showing to be stably expressed in breast, lung and pancreatic cancers $[21,33]$. However, little is known about its expression in skin cancer. To our knowledge, there is solely a study that investigated its expression in FFPE and frozen MM samples of 25 patients with primary melanoma and cutaneous or lymph node MM metastases. TFRC was the one that showed a minimum mean coefficient of variation among other genes [22]. In contrast to this, our results found TFRC to be the least stable gene beyond ACTB and HPRT1 for $\mathrm{MM}$, but the most stable one in CSCC. Moreover, we found that the best combination of two reference genes for normalizing CSCC tissue was TFRC and HPRT1. To our knowledge, this is the first study that investigated the role of TFRC and HPRT1 as potential useful reference genes for expression studies in CSCC tumour FFPE samples.

The NormFinder algorithm only analyses samples with significant signal detection. Thus, samples without intense HPRT1 and TFRC signal were lost. BestKeeper software has the advantage of including into the analysis lost $\mathrm{Ct}$ values due to low signal, and therefore a larger number of samples can be analysed. The method of direct comparison of $\mathrm{Ct}$ and standard deviation between tissues allows overview of gene stability. It is a very simple but useful technique to detect the stability of the reference genes. Combined use of these methods together with the BestKeeper algorithm allowed us to determine which of these genes is the most stable, and which is the best combination between them for CSCC and MM FFPE sample gene expression studies. Therefore, it is highly recommended to use at least two or three methods to validate appropriate reference genes for expression studies specific for different samples, as in this study.

Fixation and paraffin embedding of the tissue influence both the yield and quality of RNA [22,34,35], especially when archival FFPE tissue is used, where storage and conservation conditions are unknown. There is no method that is easily capable of accurately assessing the quality of these types of samples. We suggest that the best method to assess a sample's RNA quality is to simply determine if it generates expression data [36,37]. A main issue when dealing with RNA isolation from FFPE tissues is the pre-amplification step [38]. One of the strengths of the current study was to use a pre-amplification cDNA procedure that allows amplification of cDNA with no bias, and provides extremely high correlation between amplified and unamplified cDNA [38].

The current study has several limitations. On the one hand, TBP were excluded from analysis because of the low percentage of detection in CSCC and MM samples. This may be due to chemical modifications during fixation and storage of the tissues. However, gene deregulation along tumour progression may also account for the finding [39]. On the other hand, mRNA quality was measured in a spectrophotometer and confirmed by conventional PCR of the ACTB gene from the cDNA. It allowed us to preliminary evaluate the mRNA and to discard poor quality samples. Lack of RNA validation entails the possibility that gene expression data may be equivocal because of the routine fixation of the sample or the RNA purification method.

\section{Conclusions}

Skin cancer research focuses on genes involved in disease progression. Gene expression studies allow a rapid analysis for candidate tumour markers that can accurately detect tumour progression [40,41]. Following the MIQE guidelines for the publication of RT-qPCR experiments [42], it is crucial to assess reference genes properly. We suggest that $A C T B$ and HPRT1 in combination are the appropriate reference genes for the normalization of gene expression studies in MM FFPE samples, as is the combination of TFRC and HPRT1 reference genes in CSCC FFPE tissue. 
Author Contributions: E.C.-L. and R.F.-d.-M. participated in conception and design; O.G.-P., E.C.-L. and R.F.-d.-M. participated in the analysis, interpretation, and drafting of the manuscript for important intellectual content, and take responsibility for the integrity of the data and the accuracy of the data analysis. O.G.-P. and L.M.-V. contributed with laboratory analysis and interpretation. All authors have read and agreed to the published version of the manuscript.

Funding: This work was supported by Fundación CajaCanarias (Salucan13) and Fundación DISA (OA18/010). Consumable material and personal support (Omar García-Pérez) was financed by both institutions.

Institutional Review Board Statement: The study was conducted according to the guidelines of the Declaration of Helsinki, and approved by the Institutional Review Board from the Hospital Universitario Nuestra Señora de Candelaria, Tenerife, Spain (C.P. MO-C.I. PI-57/17 and C.P. MOC.I. PI-39/14).

Informed Consent Statement: Informed consent was obtained from all subjects involved in the study.

Data Availability Statement: All data relevant to the study are included in the article. Ct raw data.

Acknowledgments: We thank Enrique Martínez Carretero for the use of laboratory equipment at the Instituto Universitario de Enfermedades Tropicales y Salud Pública de Canarias (IUETSPC). We thank Hilaria González for technical assistance.

Conflicts of Interest: The authors have no conflict of interest to declare.

\section{References}

1. Carr, S.; Smith, C.; Wernberg, J. Epidemiology and Risk Factors of Melanoma. Surg. Clin. N. Am. 2019, 100, 1-12. [CrossRef]

2. Wei, W.; Chen, Y.; Xu, J.; Zhou, Y.; Bai, X.; Yang, M.; Zhu, J. Identification of Biomarker for Cutaneous Squamous Cell Carcinoma Using Microarray Data Analysis. J. Cancer 2018, 9, 400-406. [CrossRef]

3. Belter, B.; Haase-Kohn, C.; Pietzsch, J. Biomarkers in Malignant Melanoma: Recent Trends and Critical Perspective. Exon Publ. 2017, 39-56. [CrossRef]

4. Angi, M.; Kalirai, H.; Prendergast, S.; Simpson, D.; Hammond, D.; Madigan, M.C.; Beynon, R.; Coupland, S.E. In-depth proteomic profiling of the uveal melanoma secretome. Oncotarget 2016, 7, 49623-49635. [CrossRef]

5. Solassol, J.; Du-Thanh, A.; Maudelonde, T.; Guillot, B. Serum Proteomic Profiling Reveals Potential Biomarkers for Cutaneous Malignant Melanoma. Int. J. Biol. Markers 2011, 26, 82-87. [CrossRef]

6. Kokkat, T.J.; Patel, M.S.; McGarvey, D.; Livolsi, V.A.; Baloch, Z.W. Archived Formalin-Fixed Paraffin-Embedded (FFPE) Blocks: A Valuable Underexploited Resource for Extraction of DNA, RNA, and Protein. Biopreservation Biobanking 2013, 11, 101-106. [CrossRef]

7. Christensen, J.N.; Schmidt, H.; Steiniche, T.; Madsen, M. Identification of robust reference genes for studies of gene expression in FFPE melanoma samples and melanoma cell lines. Melanoma Res. 2020, 30, 26-38. [CrossRef]

8. Ibusuki, M.; Fu, P.; Yamamoto, S.; Fujiwara, S.; Yamamoto, Y.; Honda, Y.; Iyama, K.-I.; Iwase, H. Establishment of a standardized gene-expression analysis system using formalin-fixed, paraffin-embedded, breast cancer specimens. Breast Cancer 2011, 20, 159-166. [CrossRef]

9. Mocellin, S.; Rossi, C.R.; Pilati, P.; Nitti, D.; Marincola, F.M. Quantitative real-time PCR: A powerful ally in cancer research. Trends Mol. Med. 2003, 9, 189-195. [CrossRef]

10. Kozera, B.; Rapacz, M. Reference genes in real-time PCR. J. Appl. Genet. 2013, 54, 391-406. [CrossRef]

11. García-Sánchez, A.; Marqués-García, F. Chromatin Immunoprecipitation: Application to the Study of Asthma. In Molecular Genetics of Asthma; Humana Press: New York, NY, USA, 2016; Volume 1434, pp. 121-137. [CrossRef]

12. Huggett, J.F.; Dheda, K.; Bustin, S.; Zumla, P.S.A. Real-time RT-PCR normalisation; strategies and considerations. Genes Immun. 2005, 6, 279-284. [CrossRef]

13. Ayakannu, T.; Taylor, A.H.; Willets, J.M.; Brown, L.; Lambert, D.G.; McDonald, J.; Davies, Q.; Moss, E.L.; Konje, J.C. Validation of endogenous control reference genes for normalizing gene expression studies in endometrial carcinoma. Mol. Hum. Reprod. 2015, 21, 723-735. [CrossRef]

14. Gutierrez, L.; Mauriat, M.; Guénin, S.; Pelloux, J.; Lefebvre, J.-F.; Louvet, R.; Rusterucci, C.; Moritz, T.; Guerineau, F.; Bellini, C.; et al. The lack of a systematic validation of reference genes: A serious pitfall undervalued in reverse transcriptionpolymerase chain reaction (RT-PCR) analysis in plants. Plant Biotechnol. J. 2008, 6, 609-618. [CrossRef]

15. Zhang, X.; Ding, L.; Sandford, A.J. Selection of reference genes for gene expression studies in human neutrophils by real-time PCR. BMC Mol. Biol. 2005, 6, 4. [CrossRef]

16. Dheda, K.; Huggett, J.F.; Bustin, S.; Johnson, M.A.; Rook, G.; Zumla, P.S.A. Validation of housekeeping genes for normalizing RNA expression in real-time PCR. BioTechniques 2004, 37, 112-119. [CrossRef] [PubMed] 
17. Chari, R.; Lonergan, K.M.; A Pikor, L.; Coe, B.P.; Zhu, C.Q.; Chan, T.H.; E MacAulay, C.; Tsao, M.-S.; Lam, S.; Ng, R.T.; et al. A sequence-based approach to identify reference genes for gene expression analysis. BMC Med Genom. 2010, 3, 32. [CrossRef]

18. de Jonge, H.J.; Fehrmann, R.S.; de Bont, E.S.; Hofstra, R.M.; Gerbens, F.; Kamps, W.A.; de Vries, E.G.; van der Zee, A.G.; te Meerman, G.J.; ter Elst, A. Evidence based selection of housekeeping genes. PLoS ONE 2007, 2, e898. [CrossRef]

19. Suzuki, T.; Higgins, P.J.; Crawford, D.R. Control Selection for RNA Quantitation. BioTechniques 2000, 29, 332-337. [CrossRef] [PubMed]

20. Ripoli, F.L.; Mohr, A.; Hammer, S.C.; Willenbrock, S.; Hewicker-Trautwein, M.; Hennecke, S.; Escobar, H.M.; Nolte, I. A Comparison of Fresh Frozen vs. Formalin-Fixed, Paraffin-Embedded Specimens of Canine Mammary Tumors via Branched-DNA Assay. Int. J. Mol. Sci. 2016, 17, 724. [CrossRef] [PubMed]

21. Drury, S.; Anderson, H.; Dowsett, M. Selection of REFERENCE genes for normalization of qRT-PCR data derived from FFPE breast tumors. Diagn. Mol. Pathol. 2009, 18, 103-107. [CrossRef]

22. Lebbé, C.; Guedj, M.; Basset-Seguin, N.; Podgorniak, M.P.; Menashi, S.; Janin, A.; Mourah, S. A Reliable Method for the Selection of Exploitable Melanoma Archival Paraffin Embedded Tissues for Transcript Biomarker Profiling. PLoS ONE 2012, 7, e29143. [CrossRef] [PubMed]

23. Glenn, S.T.; Jones, C.A.; Liang, P.; Kaushik, D.; Gross, K.W.; Kim, H.L. Expression profiling of archival renal tumors by quantitative PCR to validate prognostic markers. BioTechniques 2007, 43, 639-647. [CrossRef] [PubMed]

24. Janik, M.E.; Szwed, S.; Grzmil, P.; Kaczmarek, R.; Czerwiński, M.; Hoja-Łukowicz, D. RT-qPCR analysis of human melanoma progression-related genes-A novel workflow for selection and validation of candidate reference genes. Int. J. Biochem. Cell Biol. 2018, 101, 12-18. [CrossRef] [PubMed]

25. Wang, X.; He, J.; Wang, W.; Ren, M.; Gao, S.; Zhao, G.; Wang, J.; Yang, Q. Validation of internal reference genes for relative quantitation studies of gene expression in human laryngeal cancer. Peer] 2016, 4, e2763. [CrossRef] [PubMed]

26. Walter, R.F.H.; Werner, R.; Vollbrecht, C.; Hager, T.; Flom, E.; Christoph, D.C.; Schmeller, J.; Schmid, K.W.; Wohlschlaeger, J.; Mairinger, F. ACTB, CDKN1B, GAPDH, GRB2, RHOA and SDCBP Were Identified as Reference Genes in Neuroendocrine Lung Cancer via the nCounter Technology. PLoS ONE 2016, 11, e0165181. [CrossRef] [PubMed]

27. Walter, R.F.H.; Mairinger, F.D.; Wohlschlaeger, J.; Worm, K.; Ting, S.; Vollbrecht, C.; Schmid, K.W.; Hager, T. FFPE tissue as a feasible source for gene expression analysis-A comparison of three reference genes and one tumor marker. Pathol. Res. Pract. 2013, 209, 784-789. [CrossRef]

28. Majidzadeh-A, K.; Esmaeili, R.; Abdoli, N. TFRC and ACTB as the best reference genes to quantify Urokinase Plasminogen Activator in breast cancer. BMC Res. Notes 2011, 4, 215. [CrossRef]

29. Pfaffl, M.W.; Tichopad, A.; Prgomet, C.; Neuvians, T.P. Determination of stable housekeeping genes, differentially regulated target genes and sample integrity: BestKeeper-Excel-based tool using pair-wise correlations. Biotechnol. Lett. 2004, 26, 509-515. [CrossRef] [PubMed]

30. Andersen, C.L.; Jensen, J.L.; Ørntoft, T.F. Normalization of Real-Time Quantitative Reverse Transcription-PCR Data: A ModelBased Variance Estimation Approach to Identify Genes Suited for Normalization, Applied to Bladder and Colon Cancer Data Sets. Cancer Res. 2004, 64, 5245-5250. [CrossRef]

31. Rienzo, M.; Schiano, C.; Casamassimi, A.; Grimaldi, V.; Infante, T.; Napoli, C. Identification of valid reference housekeeping genes for gene expression analysis in tumor neovascularization studies. Clin. Transl. Oncol. 2012, 15, 211-218. [CrossRef] [PubMed]

32. Guo, C.; Liu, S.; Wang, J.; Sun, M.Z.; Greenaway, F.T. ACTB in cancer. Clin. Chim. Acta 2013, 417, 39-44. [CrossRef] [PubMed]

33. Iyer, G.; Wang, A.R.; Brennan, S.R.; Bourgeois, S.; Armstrong, E.; Shah, P.; Harari, P.M. Identification of stable housekeeping genes in response to ionizing radiation in cancer research. Sci. Rep. 2017, 7, 43763. [CrossRef] [PubMed]

34. Schmeller, J.; Wessolly, M.; Mairinger, E.; Borchert, S.; Hager, T.; Mairinger, T.; Schmid, K.W.; Wohlschlaeger, J.; Walter, R.F.; Mairinger, F.D. Setting out the frame conditions for feasible use of FFPE derived RNA. Pathol. Res. Pract. 2018, 215, 381-386. [CrossRef] [PubMed]

35. Haynes, H.; Killick-Cole, C.L.; Hares, K.M.; Redondo, J.; Kemp, K.; A Moutasim, K.; Faulkner, C.; Wilkins, A.; Kurian, K.M. Evaluation of the quality of RNA extracted from archival FFPE glioblastoma and epilepsy surgical samples for gene expression assays. J. Clin. Pathol. 2018, 71, 695-701. [CrossRef]

36. Warf, M.B.; Flake, D.D.; Adams, D.; Gutin, A.; Kolquist, K.A.; Wenstrup, R.J.; Roa, B.B. Analytical validation of a melanoma diagnostic gene signature using formalin-fixed paraffin-embedded melanocytic lesions. Biomark. Med. 2015, 9, 407-416. [CrossRef]

37. Wada, S.; Noguchi, T.; Takeno, S.; Kawahara, K. PIK3CA and TFRC Located in 3q Are New Prognostic Factors in Esophageal Squamous Cell Carcinoma. Ann. Surg. Oncol. 2006, 13, 961-966. [CrossRef] [PubMed]

38. Korenková, V.; Scott, J.; Novosadová, V.; Jindřichová, M.; Langerová, L.; Švec, D.; Šídová, M.; Sjöback, R. Pre-amplification in the context of high-throughput qPCR gene expression experiment. BMC Mol. Biol. 2015, 16, 5. [CrossRef]

39. Donati, S.; Ciuffi, S.; Brandi, M.L. Human Circulating miRNAs Real-time qRT-PCR-based Analysis: An Overview of Endogenous Reference Genes Used for Data Normalization. Int. J. Mol. Sci. 2019, 20, 4353. [CrossRef]

40. Yu, B.; Zhang, Y.; Wu, K.; Wang, L.; Jiang, Y.; Chen, W.; Yan, M. CD147 promotes progression of head and neck squamous cell carcinoma via NF-kappa B signaling. J. Cell. Mol. Med. 2018, 23, 954-966. [CrossRef] 
41. Ouyang, F.; Liu, J.; Xia, M.; Lin, C.; Wu, X.; Ye, L.; Song, L.; Li, J.; Wang, J.; Guo, P.; et al. GINS2 is a novel prognostic biomarker and promotes tumor progression in early-stage cervical cancer. Oncol. Rep. 2017, 37, 2652-2662. [CrossRef]

42. Bustin, S.A.; Benes, V.; Garson, J.A.; Hellemans, J.; Huggett, J.; Kubista, M.; Mueller, R.; Nolan, T.; Pfaffl, M.W.; Shipley, G.L.; et al. The MIQE Guidelines: Minimum Information for Publication of Quantitative Real-Time PCR Experiments. Clin. Chem. 2009, 55, 611-622. [CrossRef] [PubMed] 